DOI https://doi.org/10.36059/978-966-397-145-2/1-23

\title{
THE PHILOSOPHICAL AND METHODOLOGICAL BASIS OF ANALYSIS OF THE SCIENCE OF PHILOSOPHY OF EDUCATION
}

\section{Atamaniuk Z. M.}

\section{INTRODUCTION}

In today's world, science is becoming a direct productive force, and the scientific and technological revolution is gaining ground, so the development of problems of methodology and logic of scientific research is emerging as one of the urgent tasks of philosophy. The flow of research is increasing, and the number of people involved in science is increasing. Everything requires analysis and development of research methods used in modern science.

The object of our interest in education, as a process of broadcasting previously unknown to the subject of learning, as a special form of social communication, based on sufficiently deep information and epistemological foundations. Due to education, according to G. Hegel, the ascension to the universal, that is, the individual goes beyond the individually acquired experience; direct natural ability consciously joins the achievements of culture, science ${ }^{1}$. Awareness allows you to overcome the limitations of individual existence.

Ukrainian society has an interest in the philosophy of education, its practical, social component. Researchers' interest in philosophical issues in educational activities is driven primarily by the objective and conscious role of education in solving global problems. In doing so, we observe a lack of a methodological component in research on educational philosophy. Therefore, we have set ourselves the task of

\footnotetext{
${ }^{1}$ Гегель Г.В.Ф. Энциклопедия философских наук. Москва, 1977. Т. 3. 471 с.
} 
demonstrating the philosophy of education as a component of scientific knowledge. "In modern Ukraine," education philosophy "is defined as a set of worldview theories (ideas) that determine the methodology of education and training, the formation of the appropriate type of personality"'?

\section{Philosophical and general scientific methods, techniques and criteria of scientific knowledge}

Scientific knowledge is a system of knowledge about the laws of nature, society, and thinking. Scientific knowledge forms the basis of the scientific picture of the world and reflects the laws of its development ${ }^{3}$. The structure of scientific knowledge consists of three levels: empirical, theoretical and meta theoretical ${ }^{4}$.

Contemporary philosophical and specialized literature still lacks a systematic account of the essence of the concept of "scientific". This creates some difficulties in mastering scientific information from modern philosophical methodology.

Scientists have proposed a system of philosophical means by which the nature and role of scientific knowledge are revealed. These funds include:

- logical and philosophical approach;

- philosophical and systemic method;

- structural-philosophical approach;

- system-functional approach.

2 Базалук О. Філософія: конспект лекцій: Збірник працьь Філософія: конспект лекцій: Збірник праць URL: https: //pidruchniki.com/13761025/filosofiya/ ponyattya_filosofiya_osviti_predmet_zavdannya

3 Арутюнов В. С., Стрекова. М. Наука как общественное явление: курс лекцій / В. С. Арутюнов, Л. Н.: Санкт-Петербург. 2001. 110 с. С. 67.

4 Кохановский В. П., Золотухина Е. В., Лешкевич Т. Г., Фатхи Т. Б. Философия для аспирантов: Учебное пособие. 2003. 448 с. С. 56. 
Considering the application of the above tools to the analysis of knowledge, the concept and understanding of their scientific nature is established.

The leading role in this process belongs to the system of philosophical and general scientific methods, techniques and criteria objectivity, the principle of sufficient reason, object-subject system and taking into account the axiological approach.

Applying the philosophical principle of objectivity to the analysis of knowledge makes it possible to identify in their content such parameters, which reflect the properties, qualities, and relations of objects of reality as they are without any imagination or subjective bias. Based on the principle of objectivity purposefully applied privatescientific means - verification and falsification to approbation of knowledge on the subject of their scientific.

Using the logical principle of sufficient reason allows us to determine the empirical grounds, rational prerequisites, and intellectualintellectual means. With their help, knowledge in scientific form is constructed and argued. Here they act as a theory or hypothesis. The role of this principle in the process of defining the scientific knowledge is given special attention by the famous German philosopher G.V. Leibniz: "No phenomenon can be true or true, no statement - just without sufficient reason why the case is the case, not otherwise"

A very important basis for the formation and functioning of scientific knowledge is the presence of a certain subject-object system of scientists. In the presence of knowledge is recognized as scientific, but here it is necessary to take into account the objective and subjective prerequisites, conditions, and factors present in the field of cognitive and professional activity of scientists, as well as logic-formalization and technical means.

\footnotetext{
5 Лейбниц Г. В. Сочинения в 4-х т. Москваю. 1984. Т. 1. 636 с. С. 418.
} 
The axiological aspect of the establishment of scientific knowledge is very important in characterizing science as a social institution. But it is not yet sufficiently developed in the field of the sociology of science, first introduced by the post-positivist philosopher T. Kuhn ${ }^{6}$.

In our opinion, increasing the value of scientific knowledge will be carried out subject to the following principles:

- observance of strict objectivity and specific-historical consideration of the studied object, regardless of the presence of ideological relations to it;

- scientific questions should be raised from the perspective of problems of human being, its essence, and existence with access to practical personal needs;

- the interpretation of scientific discoveries and inventions must be made in the context of spiritual culture;

- consideration of scientific discussion problems should be conducted in the language of tolerance, tolerance, in the dialogue of different points of view on the discussed issues (for example, on the issue of nuclear energy);

- the construction of scientific theories should be carried out in the context of the formation of the whole culture of society, which will ensure its progress.

These are, in our opinion, the basic philosophical and scientific methods and methods of determining the scientific knowledge.

Exploring the criteria of truth for establishing the scientific knowledge, we based on the study of the experience of lecturing and conducting seminars in philosophy and special scientific disciplines have developed criteria that determine the scientific knowledge and

\footnotetext{
${ }^{6}$ Кун Т. Структура научных революций. Москва. 1977. 273 с.
} 
determine their difference from ordinary, false, religious, misinformation.

Such criteria include.

- Objectivity. According to this criterion, knowledge can only be recognized as scientific, which in its content reproduces the properties, qualities, relations of real objects of reality, taken by them and not yet known. In this case, knowledge must be presented without bringing into their content anything subjective or beyond, supernatural.

- Rationality. With the help of the system of logic-reasoning tools at the level of the mind, knowledge acquires the status of science, if they are justified, substantiated and verified based on rules and laws of logic. According to this criterion, different degrees of scientific knowledge are defined, which allows to distinguish them from ordinary ones. The latter is controlling in nature and is based on "thought", "authority" and other idols of the mind. In scientific knowledge, not just something is communicated, but the necessary arguments, evidence, according to which it is true. There is a logical principle of sufficient grounds, which, as noted, indicates that no phenomenon can be true, reliable without sufficient reason.

- Essentially of knowledge. The application of this criterion to the analyzed knowledge allows us to reveal its scientific nature, provided that it is directed to a recognizable object for the reproduction of essential, stable, repetitive properties, qualities, relations of objects and objects of reality.

- Systematic organization of knowledge. Knowledge acquires the status of science if it is analyzed, ordered, classified, sorted by generic, species characteristics of objects and objects of reality using logical and intellectual means. Only such a mental operation can determine the qualitative feature of scientific knowledge about the ordinary. Here the main role is played by the basic principles of ordering knowledge in the form of theory and detailed theoretical concept. 
- Verification of knowledge on their scientific truth. Not all new knowledge in the field of scientific knowledge can be recognized as scientifically true. Their functionality can also be misguided and misinformation. It is possible to distinguish this knowledge and to determine their scientific validity only by practical and logical means. Practice of scientific observations, experiments and logical means of thinking allow us to argue, prove and establish the truth of scientific knowledge.

- The theoretical basis for the delimitation of the scientific form of true knowledge from everyday life. The system of functioning of knowledge of science includes various forms of truth, which are inherent in both every day and scientific knowledge. This creates some difficulty in distinguishing them. As such a criterion is theoretical conceptual means of scientific knowledge. Here is an example that illustrates the distinction between two forms of truth at the everyday and theoretical levels of knowledge. The sentence "Snow White" can be qualified as true. This truth belongs to the sphere of everyday knowledge. But when we apply theoretical means to analyzed knowledge in the form of "Snow White," we refine this sentence in the form of scientific truth - "Snow White." Here it is presented as the effect of the influence of incoherent reflected light on visual receptors. This sentence is no longer a mere statement of observations, but a consequence of scientific theories - the physical theory of light and the physiological theory of visual perception.

- Socio-philosophical bases of scientific knowledge. As a result of the efforts of modern philosophers and specialists in various fields of social sciences, a basic foundation has been developed that determines the worldview and methodological essence of scientific knowledge. This is the basis of the integrity of the ideological and methodological orientation of scientific knowledge and their effectiveness in solving social problems of cultural importance. This 
indicates that in all fields of scientific knowledge the sociophilosophical aspect is decisive. The proof of this is that philosophy is closely linked to all specific social sciences - law, economic science, cultural sciences, sociology, political science, psychology, pedagogy, philology and art while generalizing the results of these sciences in general about the person. Socio-philosophical background of scientific knowledge is expressed in triple dimension: outlook-methodological, content-information and social-activity. According to these parties, relationships and relationships determine the main socio-philosophical background of scientific knowledge.

Definition and significance of logical techniques and methods in scientific knowledge, we suggest considering in the following direction:

a) Before exploring the object, the phenomenon must firmly determine for itself the installation of the conceptual content of the concepts of "reception" and "method" in the following form:

1) Reception - is epistemological and logical orientation of mental means - analysis, synthesis, comparison, abstraction, idealization, etc. on the investigated object;

2) method - its system of specific principles, techniques, rules, requirements of consistency, evidence and consistency, which must be guided in scientific knowledge;

b) when applying each of the techniques and methods to the analysis of the object should know deeply their specific content:

- analysis - the real or imaginary division of the object into components, and synthesis - their unification;

- abstraction - the imaginary process of distraction from several properties and relations of the studied phenomenon with the simultaneous selection of properties of interest to the researcher;

- idealization - an imaginary procedure associated with the formation of abstract (idealized) objects that are in principle not feasible in reality ("point", "perfect gas", "absolutely black body", etc.); 
- induction - the movement of thought from the single (experience, facts) to the general (with a generalization in conclusions) and deduction - the convergence of the process of cognition from the general to the single;

- analogy (correspondence, similarity) - the imaginary establishment of similarity in some parties, properties, and relations between non-identical objects. Based on the revealed similarity, a corresponding conclusion is drawn - a conclusion by analogy;

- formalization - a method by which considerations of objects are transferred into the plane of operation with signs (formulas). The relation of signs is replaced by statements about the properties and relations of objects;

- modeling - a method of exploring certain objects by reproduction: their characteristics on another object-model, which is an analog of a particular fragment of reality (real or imagined) of the original model. There must be some similarity (similarity) between the model and the object of interest to the researcher - in physical characteristics, structure, functions, etc.;

- axiomatization - an imaginary way of constructing scientific theories, in which they base some initial provisions - axioms (postulates), from which all other provisions of these theories are deduced from them in a purely logical way using evidence;

- hypothetico -deductive method - a logical way of theoretical study of the subject, the essence of which is to create a system of deductively related hypotheses from which statements about empirical facts are derived.

This philosophical and methodological basis (the philosophical basis of scientific knowledge; logical techniques and methods of scientific knowledge; methods, techniques, and criteria that ensure the scientific knowledge), through which the science of knowledge is established. Knowledge and purposeful use of its scientific process will 
help to promote the philosophy of education as a scientific discipline. In this regard, it is necessary to consider the social origins of the formation of educational philosophy, which will give more arguments to justify its allocation as an independent scientific discipline.

Science occupied a dominant position in society, which at the end of the nineteenth century gave rise to such a worldview as scientist. Where science is of the highest value to both culture and society. At the end of the twentieth century, the crisis, environmental disasters associated with the development of scientific and technological progress, led to disappointment in science. Because science was no longer responsible for the social consequences of its use. Nowadays, in the 21 st century, science has greatly expanded its capabilities: the Internet, video, and satellite communications have erased all spatial and temporal boundaries. Now, in our lives, science must return to spirituality, to humanity. It should be understood that humans are part of the biosphere and live by its productivity, which, unfortunately, is significantly limited. In the biosphere, their laws and violate them is unacceptable.

Tolstoukhov A., Parapan I. aptly characterize the science of the 21 st century "... proudly-independent ideal of scientific rationality of classical science, when an object appeared as a given" by itself "..., transformed into non-classical, within which man, as the subject of knowledge is located "inside" nature, the biosphere, along with their values and worldviews" ". It is possible to distinguish classical science, non-classical and post-classical. At the classical and non-classical stages of its development, science found support only in the values of technogenic civilization and denied the values of traditionalist cultures. Post-classical science included modern processes, solutions to problems of a global nature and the choice of life strategies of mankind. PostClassical Science embodies the ideals of "open rationality" and actively

\footnotetext{
${ }^{7}$ Глобалістський контекст. Філософська думка. 2001. № 6. С. 8-24. С. 19.
} 
participates in the search for new worldviews that determine the strategies of modern civilizational development ${ }^{8}$.

\section{Development of the philosophy of education as a modern science}

The classical paradigm of education that emerged based on the philosophy of the Enlightenment cannot be fully identified either with the image of science, with the idea of a universal unified mind, nor with the normative of the philosophy of the Enlightenment.

It can be concluded that the development of the philosophy of education is fully explained by the hopes of scientists and practitioners in this way to solve the problems of modern education and to realize its functional imperative as a factor in the formation of post-industrial society. Thus, the analysis of the social origins of the formation of educational philosophy provides sufficient grounds for finding the validity of its allocation as an independent scientific discipline to serve the complex of social needs associated with the ordering and management of large-scale and radical processes of change in educational systems.

The interaction between philosophy and education has always played a significant role in the development of mankind, especially after the Enlightenment, which laid the foundations of philosophical reflection on the educational process, paying attention to the direct relationship of the level of education of society with the level of its social progress.

The main sources of this area of philosophical research include fragments of the major works of Plato, Aristotle, Avicenna, Thomas Aquinas, J. Locke, J.-J. Rousseau, J. Dewey, J. Piaget and other thinkers who paid attention to the social analysis of education. A special place in this list is the treatise by J.-J. Rousseau, devoted directly to the problems

\footnotetext{
${ }^{8}$ Степин В. С. Теоретическое знание. Москва. 2000. 744 с. С. 713.
} 
of education and its socio-practical significance. As an independent philosophical direction, the philosophy of education finally emerged at the end of the XX century. At the turn of the century, it is represented by such names as R. Mitchell, A. Bloom, N. Postman, J. Bruner, M. Rosenberg, and others. Its main research task is to analyze the productivity of modern education and to identify the main ways of its further transformation in the direction of adaptation to the new civilizational conditions.

A P. Sorokin point out that classical European education has lost spiritual values ${ }^{9}$. Not only education has changed, but for the mass of young people the meaning of its acquisition has begun to disappear. The pragmatic nature is increasingly evident: getting a high paying profession, making a career, succeeding, and more. Changes in values could not but reflect changes in the attitude of young people to education. The value of highly skilled labor has risen, especially in commercial structures. If once a specialty was chosen at the call of the soul, no more appeal to the material side of life, choose a specialty that would bring in the future money, material security. So now education goes along with material well-being and has become one of the means of achieving it.

The classical system of education is oriented on the human intellect, which is guided by science, puts it for authority, science has become above moral values. H. Ortega-i-Gasset states: “... we meet a type of scholar who has never been seen by history. He knows from all that an educated person knows, knows only one science, and even in this science knows only that small area, which he is actively exploring. ... The specialist is well aware of his little corner of the universe, but has no clue about everything else" 10 . This state of "deafness", as defined by

${ }^{9}$ Сорокин П. Социальная и культурная мобильность. Человек. Цивилизация. Общество. Москва. 1992. 542 с. С. 415.

${ }^{10}$ Ортега-і-Гассет Х. Бунт мас. Вибрані твори. Київ. 1994. 420 с. С. 82-83. 
H. Ortega-i-Gasset, arose precisely because of the demoralization, dehumanization of society. At the end of the twentieth century, when humanity was threatened with its existence (nuclear threat, environmental), the crisis of the European classical model of education was replaced by a non-classical model of education, which put at the center of a moral person responsible for their actions. Maslow A. identifies two approaches to learning. The first is: “... they work to convey to children the knowledge they need to live in an industrial society. No different imagination or creative ability. Supporters of the second approach - a humanist-oriented minority of educators who aim to self-actualize and self-transcend their students"11. The very first approach can be defined as the classical model of education, where education suppresses creativity, intuition, instead of developing them. And the second approach is the transition to a non-classical model of education.

The main aspect of modern Ukrainian education is the national factor. In any country, education is national. Education can mobilize the culture of the people, to prepare a new intellectual person who is to become a new generation of nation. It should be based on the cultural and historical values of the people, their traditions and spirituality. The development of its cultural heritage by society becomes dominant in the education system. After all, on the heritage and traditions of the past, education and the spirituality of our young generation must be enriched and formed. Education shapes a young person's personality, a sense of belonging to a particular society. Educational activity is at the same time socialization of the young person because in the process of learning it acquires not only scientific knowledge but also knowledge of life experience. Therefore, education must be directed to cultural and spiritual origins, national revival.

${ }^{11}$ Маслоу А. Новые рубежи человеческой природы. Москва. 1999. 425 с. C. 166 . 
In the 21 st century, the education of Ukraine is being modernized, entering the Bologna process, which involves not only improving the professional level of specialists but also the cultural, training of specialists of the state and international level. This means that the diplomas of Ukrainian graduates will be recognized abroad. Each faculty has online sites where students can find important topics for discussion, guidelines, and required literature for lectures and practicals, and more. Students were able to get an education in several educational institutions at the same time. In higher education, there was a transition to two-stage training: bachelor's and master's degrees. Private educational institutions have emerged, paid education that is now available to mostly wealthy citizens. At the present stage, a new approach in the field of education has emerged. It centers on the problem of personality with its goals, strategies, lifestyle.

Other examples of this kind can be cited, but from what has been said, it is necessary to draw the basic conclusions for the education system: 1) The central figure in any education system was a teacher. The personality of the teacher came second after God (or gods) and after the ruler. Moreover, the rulers themselves, who, of course, were trained by the most famous teachers, treated them as the most outstanding men of their time. No one could be equal to the teachers in their importance for the people and the state: neither politicians, nor generals, nor any other prominent public figures. 2) The next major figure was a student who considered it his greatest honor and greatest happiness to learn knowledge from a renowned teacher. Therefore, the student with absolute humility and attention treated his teacher, listened to his every word, memorized everything that the teacher said, and after going through this great school, he followed the path of his teacher. 3) The purpose of education was not only the transfer of knowledge but also the upbringing of the student in the appropriate spirit, that is, in the spirit of the outlook and outlook that the teacher had. 4) Obtaining appropriate knowledge, comprehension of truth and wisdom was only the first stage 
of learning and education. The next stage was the realization of the acquired knowledge in the individual and public life, that is, the acquisition and transfer of knowledge were never formal and abstract, they were always in one way or another consistent with the real-life, life of the people and the state, and therefore the education system always and everywhere, in all societies and states was considered a paramount state concern. 5) The teacher and the student were considered noble men and their nobility consisted of acquiring and transferring the whole system of knowledge, and then in applying this knowledge to the most serious tasks facing society and the state.

Developing in this way, having a specific purpose of activity and fulfilling its functions, education aims to satisfy the relevant social needs and interests. As a result, social relations are stabilized and various activities of members of society are coordinated. The functioning of education, the performance of people within this social institution of certain roles are determined by the social norms of its internal structure. It is these norms that determine the compulsory order, establish the measure, standard of behavior of people, directing social activity ${ }^{12}$. In this regard, it should be noted that education is integrated into the system of social institutions. Only such a unified system can ensure and guarantee the functioning of society. Without social institutions, there is no society at all, humanity as a collective entity.

In our view, the phenomenon of education is manifested in the changing social role of education in the modern world, above all, as a sphere of employment and as a specific industrial sector, in which a large mass of the population is involved. The most obvious can be considered the emergence, together with students, educators and teachers, education workers and related industries that provide the educational process (determining the directions and content of training, preparation and publication of textbooks and manuals, production of

12 Лукашевич М.П., Туленков М.В. Соціологія. Київ. 2004. 456 с. С. 34. 
technical training, computer educational process software and software, construction and operation of educational buildings, financing of educational process, etc.). New masses of the population are involved in the educational process, combining learning with work. New sources of educational information are emerging: the press, radio and multichannel television, audio and video cassettes, and the Internet. Hence, the need to consider pedagogical processes in a broader, social and methodological context. This is evidenced by the new concepts of education that have emerged recently.

Today's discussions about education are designed to radically rethink the role and content of this fundamental public institution. A key point in these discussions is to consider education not in a narrow technological context but a broad historical, social and cultural context. Unfortunately, today our education is most often designed to assimilate ready-made knowledge, not to solve problems. Problem-centricity, dialogism, and debatability have not yet become the norm of learning. It is still dominated by monological, preaching models of knowledge transfer from the older generation to the younger. As a result, students, knowing the information, do not know how to see in their surrounding life problematic situations, correctly formulate problems, independently solve them, etc.

Education is one of the most important indicators of the quality of life of a society, it affects its economic and cultural development. It is a kind of social institution, without which the nation is not able to selfidentify and develop. Education must be spiritual-related, return to a humanization aimed at national revival. Modern education allows to improve the abilities of students and students, to independently analyze and express their opinions, to defend their position. All this in the future, after the completion of training, will allow you to navigate social processes, as well as influence the decision-making of society, adapt to the social environment. Therefore, education becomes one of the main determinants of the spiritual culture of youth. 
Of course, an educated person may also be a person who has no formal education, above all higher education but is engaged in selfeducation. However, in modern conditions, education is obtained primarily in higher education. Higher education plays a significant role in social transformation. Many researchers emphasize that today the viability of any country, including ours, depends on its orientation on the development of the social institutions of education, including higher education, on the acquisition of the qualities of social subjectivity by this institute. Thus, it can be said that the reform of higher education is caused not only by the intellectualization of most spheres of public life, but by the need to form a personality whose quality would meet the challenges of the times. That is why today, the focus of modern educational practices is not the translation of knowledge (although it is important), but the development of the individual is intellectual, spiritual, moral and ethical, etc. The latter is the main idea of a new educational human-centric paradigm.

A special sphere of spiritual culture is science. Science is "an area of culture that is associated with specialized activities to create a system of knowledge about nature, society, and man" ${ }^{\prime 13}$. Science is one of the most important determinants of spiritual culture. "Its special place in spiritual culture is determined by the importance of knowledge in the way of being human in the world, in practice, in the material and material transformation of the world"14. It is through cognition that man becomes aware of the world and himself, he is formed as a person. Spiritual culture and all its forms are inextricably linked to knowledge. And science has an important place in human life. It has become a kind of epicenter of culture, helping a person to perceive the reality that surrounds him. "The results of scientific knowledge are constructed in

${ }^{13}$ Культурология. ХХ век. Энциклопедия. Т.2. СПб. 1998. 447 с. С. 71.

${ }^{14}$ Новоселецький М.Ю., Панасюк А.Л. Місце наукового світогляду у житті людини. Проблеми реалізації духовного потенціалу молоді: Матер. всеукр. наук.технічної конф. Рівне 7-8 грудня 2000 р. Вип. 2. Рівне. 2002. 112 с. С. 53. 
such a way as to exclude everything personal. Therefore, science is geared to obtain such knowledge that does not depend on either man or mankind. No other component of spiritual culture (no art, no ideology, no religion, etc.) has this goal in mind"15.

For a long time in the history of mankind, science gave an idea of the infinite possibilities of man and his mind, of the infinite and inexhaustible nature. Man has modified, adapted and conquered nature. As a result, humanity faces the problem of survival.

Everything is alive, including we humans depend on the conservation and integrity of the biosphere. Therefore, the focus of modern man is the problem of human interaction with the environment. As a result of improper management of the person, the ecological situation is over. Humanity is aware of this problem, but unfortunately, ecological culture is now poorly developed among the population. There is still no interaction, unity of man with the environment in which he exists. The revaluation of values has led to the destruction of the sacred principles of morality, and man increasingly forgets his place in the biosphere. Man, living in the natural environment, carefree and safe, can't understand how serious this problem is and is a great threat to his life.

The impact of science on culture was so strong that man became convinced of his limitless possibilities to dominate nature. And all this led to the separation of human culture from natural existence, as well as to the crisis phenomena in culture.

Science occupied a dominant position in society, which at the end of the nineteenth century gave rise to such a worldview as scientist. Where science is of the highest value to both culture and society. At the end of the twentieth century, the crisis, environmental disasters

${ }^{15}$ Новоселецький М.Ю., Панасюк А.Л. Місце наукового світогляду у житті людини. Проблеми реалізації духовного потенціалу молоді: Матер. всеукр. наук. технічної конф. Рівне 7-8 грудня 2000 р. Вип. 2. Рівне. 2002. 112 с. С. 53. 
associated with the development of scientific and technological progress, led to disappointment in science. Because science was no longer responsible for the social consequences of its use.

Nowadays, in the 21 st century, science has greatly expanded its capabilities: the Internet, video, and satellite communications have erased all spatial and temporal boundaries. There are many possibilities for the modern man. Life has become diverse, diverse. The Internet has become a cultural model for a new society. Modern scientific achievements have changed the life of society; they have influenced all spheres of human life. And although anti-Scientism prevails in society, in culture, science holds a major place. Of course, this social progress has both positive and negative sides. The person was allowed to access all practical sources of information and to make his own choice. But at the same time, more and more problems and conflicts are facing the person. The main problem of human existence is the environmental problem because the person in the XXI century has become more unprotected.

The pace of growth of information in a postmodern society requires constant updating of educational resources, their improvement and taking into account the latest trends in modern education on a global scale. The main trend of the modern philosophy of education is the search for new educational paradigms that are suitable for the needs of modern society, in which the concept of lifelong education becomes an important vital necessity. Due to the tendency for constant increase of information load and, accordingly, accumulation of new socially significant knowledge, modern man is not enough for successful selfrealization of his previously acquired knowledge.

Postmodern civilization demands from us a new understanding and awareness of the essence of the educational process and its social productivity. In such circumstances, there is a need to create new educational programs that would take into account the trends of social development and contribute to the rapid socialization of people, their 
adaptation to new social conditions. Therefore, the problem of the correlation between science and philosophy of education, in modern conditions, pays special attention and requires appropriate analysis. All efforts of the modern philosophy of education are aimed at finding and introducing into modern education such an educational paradigm that could positively solve the global and other most acute problems of modern humanity.

The most obvious can be considered the emergence, together with students, educators and teachers, employees of the education sector and related industries that provide the educational process (definition of directions and content of training of specialists, preparation and publication of textbooks and manuals, production of technical training tools, computers educational process software and software, construction and operation of educational buildings, financing of the educational process, etc.). New masses of the population are involved in the educational process, combining learning with work. New sources of educational information are emerging: the press, radio and multichannel television, audio and video cassettes, and the Internet. Hence, the need to consider pedagogical processes in a broader, social and methodological context. This is evidenced by the new concepts of education that have emerged recently.

According to many researchers, educational processes are influenced by education as an objectively determined process of increasing the overall interdependence of countries and alliances of countries in the context of widening the horizons of the modern world. The cultural component of globalization is based on new technologies of knowledge production, communication, which result in the rapprochement of peoples in cultural terms. One consequence of cultural globalization is the monopolization of information, education and spiritual space by mass media. It is an ideological imperialism that causes most humanity to be alienated from the possibility of using even transformed forms of information. There is a 
growing suppression of human personality as a sociocultural phenomenon. They are transformed into a client, subject to the standards of the "society of consumption", deprived of the opportunity to choose and create educational and cultural environments according to their value standards.

\section{CONCLUSIONS}

The philosophical and methodological basis of scientific knowledge, logical techniques, and methods of scientific knowledge, techniques, and criteria that ensure scientific knowledge - with their help establish scientific knowledge. Knowledge and purposeful use of it in the scientific process contributes to the establishment of the philosophy of education as a scientific discipline. We have considered the social origins of the formation of educational philosophy and the arguments for justifying it as an independent scientific discipline.

In our view, the phenomenon of education is manifested in the changing social role of education in the modern world, above all, as a sphere of employment and as a specific industrial sector in which a large mass of the population is involved.

It is quite natural that the development of educational philosophy requires scientific substantiation and philosophical reflection, namely: rethinking pedagogical ideas through their scientific inventory and further theoretical reconstruction, defining the ideal of the enlightened person and the influence of philosophy on education. The solution of these problems is possible on the basis of a new rationality, which, first, focuses attention on the reproduction of the conditions and structures of problematic situations in which modern man falls in his relationship with reality, secondly, the object of which is the reality of human action, the reality of becoming and the formation of reality through activities that involve the selfdevelopment of its subjects. 


\section{SUMMARY}

The paper considers a system of philosophical means by which the essence and role of scientific knowledge are revealed. These funds include:

- logical and philosophical approach;

- philosophical and systemic method;

- structural-philosophical approach;

- system-functional approach.

Considering the application of the above tools to the analysis of knowledge, the concept and understanding of their scientific nature is established.

The leading role in this process belongs to the system of philosophical and general scientific methods, techniques and criteria objectivity, the principle of sufficient reason, object-subject system and taking into account the axiological approach.

The development of educational philosophy requires scientific substantiation and philosophical reflection

The main aspect of modern Ukrainian education is the national factor. In any country, education is national. Education can mobilize the culture of the people, to prepare a new intellectual person who is to become a new generation of nation. It should be based on the cultural and historical values of the people, their traditions and spirituality.

\section{REFERENCES}

1. Арутюнов В. С., Стрекова М. Наука как общественное явление: курс лекцій / В. С. Арутюнов, Л. Н.: Санкт-Петербург. 2001. 110 c. С. 67.

2. Базалук О. Філософія: конспект лекцій: Збірник пращь Філософія: конспект лекиій: Збірник праць URL: https:// pidruchniki.com/13761025/filosofiya/ponyattya_filosofiya_osviti_pred met_zavdannya 
3. Гегель Г.В.Ф. Энциклопедия философских наук. Москва, 1977. T. 3. $471 \mathrm{c}$.

4. Карнап Т. Значение законов: объяснение и предсказание. мир философии: Книга для чтения. В 2-х ч. Ч. 1. Исходные философские проблемы, понятия и принципы. Москва. 1991. С. 586-596.

5. Кохановский В. П., Золотухина Е. В., Лешкевич Т.Г., Фатхи Т. Б. Философия для аспирантов: Учебное пособие. 2003. 448 c. C. 56.

6. Кузнєцов В. Про стан та перспективи розвитку методологічних досліджень науки. Філософська думка. 2005. № 6. C. 3-31.

7. Культурология. ХХ век. Энциклопедия. Т. 2. СПб. 1998. 447 c. C. 71.

8. Кун Т. Структура научных революций. Москва. 1977. $273 \mathrm{c}$.

9. Лейбниц Г. В. Сочинения в 4-х т. Москваю. 1984. Т. 1. 636 c. С. 418.

10.Лукашевич М.П., Туленков М.В. Соціологія. Київ. 2004. 456 c. C. 34.

11.Маслоу А. Новые рубежи человеческой природы. Москва. 1999. 425 c. C. 166.

12.Матвієнко П. В. Дискретно-континуальні перетворення та породження нових смислів, тлумачень, інтерпретацій. Вісник Харківського наџіонального університету. 2001. № 57. С. 89-92.

13.Новоселецький М.Ю., Панасюк А.Л. Місце наукового світогляду у житті людини. Проблеми реалізації духовного потенціалу молоді: Матер. всеукр. наук.-технічної конф. Рівне 7-8 грудня 2000p. Вип.2. Рівне. 2002. 112 с. С. 53.

14.Ортега-і-Гассет Х. Бунт мас. Вибрані твори. Київ. 1994. 420 c. C. $82-83$. 
15.Перестройка мышления и научное познание: монография. АН УССР. Ин-т философии. Киев. 1990. 229 с.

16.Ракитов А. И. Анатомия научного знания. Москва. 1969. $206 \mathrm{c}$.

17.Сорокин П. Социальная и культурная мобильность. Человек. Цивилизаиия. Общество. Москва. 1992. 542 с. С. 415.

18.Степин В.С. Теоретическое знание. Москва. 2000. 744 с. C. 713 .

19.Толстоухов А., Парапан I. Науковий розум і гуманістичні цінності: Глобалістський контекст. Філософська думка. 2001. № 6. C. 8-24. C. 19.

20.Ушаков Е. В. Введение в философию и методологию науки. Москва. 2005. 528 с.

\section{Information about the author:} Atamaniuk Z. M.,

Candidate of Philosophy, Associate at the Department of Philosophy, Sociology and Management of Socio-Cultural Activity, State Institution «South Ukrainian National Pedagogical University named after K. D. Ushynsky» 26, Staroportofrankivska str., Odesa, 65000, Ukraine 